\title{
STRATEGIES OF CONTINUOUS FOREIGN LANGUAGE TRAINING AT HIGHER SCHOOL IN PROFESSIONAL INTERACTION OF NON- LINGUISTIC SPECIALISTS
}

Irina Lapteva $^{1 *}$, Alexander Projoga ${ }^{2}$, Elena Pahmutova ${ }^{3}$

${ }^{1}$ Doctor of Philosophy, Mordovia State University, Foreign language Department, Saransk, Russia, ${ }^{2}$ Doctor of Philology, Mordovia State University, Foreign language Department, Saransk, Russia, ${ }^{3}$ Doctor of Pedagogy, Mordovia State University, Foreign language Department, Saransk, Russia

Email: "laptevaiv@yandex.ru, alex_projoga@gmail.com, pahmutova@mail.ru

Article History: Received on $19^{\text {th }}$ June, Revised on $23^{\text {rd }}$ August, Published on $26^{\text {th }}$ August 2019

\begin{abstract}
Purpose: The optimization of the educational process by teaching strategies for autonomous foreign language training at higher school during the professional interaction of non-linguistic specialists.

Methodology: Among theoretical methods of this experimental and review study there is the analysis of psychological and pedagogical approaches to the solution of the problems of modern language education at Russia Universities, questionnaire of linguistic preference for statistical analysis among students of nonlinguistic departments.

Main findings: 1) the questionnaires of nonlinguistic students were analyzed to identify possible fields of multicultural professional interaction and use of a foreign language for other purposes by future specialists; 2) the possibilities of autonomous learning for professional purposes were found out and the strategies for self-educational and cognitive activity were indicated; 3) the proposed strategies are believed to improve the continuous foreign language training.

Implications: The tools of independent educational-cognitive activity can be useful for students to optimize the process of language learning at the University. As well as the teaching strategies for autonomous learning, aimed at multicultural interaction in the process of language professionally - for higher school teachers.

Novelty: Foreign language training for future professionals is considered as a multifaceted educational product with a clear and didactic-based orientation to a profession.Based on the research results, the main reasons for complex educational strategies of autonomous training are identified.
\end{abstract}

Keywords: Continuous study, Professional interaction, Higher school, Non-linguistic specialists, Foreign language training, learning strategies.

\section{INTRODUCTION}

Faltering economic relationship between Europe and Russia has not influenced on intercultural and professional experience exchange. Research grants, broad prospects of study curriculum choice, professional abroad internship, give chance for every foreign language advanced student with its numerous, well-thought-out and financing opportunities.

Contemporary Russian Higher Education reforms should take into account the fact that foreign language training for future professionals is a multifaceted educational product with a clear and didactic-based orientation to a profession. It requires knowledge of many competencies (e.g. lingo-professional, communicative, socio-cultural, etc.) for multicultural foreign language communication. The prerequisite of such knowledge should be a continuous linguistic education, based on the strategies for Autonomous learning, promoting intercultural foreign language communication and successful professional collaboration to increase the level of language competence with the subsequent possibility of integration into the world community.

Higher school education involves the inculcation of language skills for multicultural professional interaction with foreign specialists of the same field, getting information from foreign-language publications, both in production activities, and science. Therefore, foreign language teaching should be continuous throughout the learning process. It should start with first-stage (undergraduate) continue throughout Master up to postgraduate courses.

The problem of modern Russian University language education is that the Federal State Educational Standards do not provide a curriculum with foreign language during senior years of Bachelor educational program. As a rule, foreign language training includes only first and second (sometimes third) terms(Educational program of higher education, 2016). A break in language learning for $2.5-3$ years negatively affects linguistic, communicative, and socio-cultural competencies.

According to the new educational standards of higher education, the total academic hours of Foreign language discipline for bachelor/master students were reduced to the minimum ones. To make changes to the Federal State Educational Standards of Russia is impossible. In our opinion, there exists an urgent need to ensure continuity of language learning, because (as experience shows) the process of language learning has often to start from the very beginning, almost from scratch, and this break has a destructive effect on the preservation language skills of students. Therefore, a special foreign 
language form of learning, namely, independent learning activity as a part of autonomous extracurricular training, should be organized and learning strategies should be indicated.

\section{LITERATURE REVIEW}

A lot of Russian and foreign researchers deal with the issues of higher education (Bermus, 2003; Sazonov, 2006; Lapteva\&Pahmutova, 2010; Stork, 2011). E.g., A.G.Bermus and A. Stork in their works raise the problems related to the management of quality of higher professional education, which is important in the context of this research.

The important role for the paper played key provisions of student-centered learning (Yakimanskaya, 1995; Huneke, 2000), using of info-communication technologies training (Polat, 2000), and basic principles of the competence approach in scientific works (Zimnyaya, 2013; Bermus, 2003; Mitusova, 2008; Cofer, 2000).

Currently, there are quite a number of classifications of strategies (Bimmel\&Rammpillon, 2000; Ellis, 1994; Wolff, 1992; and others). In this study, we rely on the classification of P. Bimmel\& U.Rammpillon (2000) due to its accuracy, completeness, demonstrativeness, and compactness. They distinguish three main groups of cognitive (direct), metacognitive (indirect) and compensatory strategies.

Metacognitive ones are of the most interest for this study, namely:

- Regulatory strategy. Concentration on the learning process, neutralization factors that impede the learning process; defining the goals and their achieving; listing of necessary actions to achieve a certain goal; setting specific foreseeable tasks; organization of activities.

- Affective strategies. Neutralization of negative emotions; organization of work without stress; self-monitoring of educational activity efficiency; promoting oneself for a successful assignment.

- Compensatory strategies. Formulation and confirmation/rejection of hypothesis; use of gestures; use of paraphrase/describe the words and synonyms.

- The strategy of social interaction. Wish to work in pair, group (can be online); developing tolerance toward other cultures, desire to understand other people's feelings.

In the framework of the competence approach, teachers and researchers of Mordovia Ogarev State University (www.mrsu.ru) conduct empirical researches, devoted to the problems of professionally oriented teaching of foreign languages in Russian Universities (Federal state educational standards, 2018) as well as learning strategies.

\section{METHODOLOGY}

The theoretical significance of the work lies in the choice of theoretical methods, including the analysis of psychological and pedagogical approaches to the solution of the problems of modern language education at Russia Universities, in accordance with the new national standards in the field of professional education (Polat, 2000; Slastenina, 2006; and others).

The research hypothesis is to improve continuous foreign language training through the proposed strategies in non-linguistic higher schools.

The purpose of this study is to find a solution to the problem of teaching load reduction for Foreign language discipline in higher school and to find ways of optimization of the educational process by teaching strategies for autonomous learning.

To achieve this objective, it is proposed to undertake the following tasks:

The first stage: to develop a questionnaire of linguistic preference for statistical analysis among bachelor and master students of nonlinguistic departments to identify possible fields of multicultural professional interaction and use of a foreign language for other purposes by future specialists.

The second stage: to show the possibilities of autonomous learning for professional purposes and to indicate the strategies for self-educational and cognitive activity.

Methodological framework of this study is based on humanistic principles of education, psychological and pedagogical concepts of personality development, key provisions of student-centered (Yakimanskaya, 1996), competence (Federal state educational standards, 2018) and acmeological approaches (Katchalov, 2004), the use of project and information and communication technologies (Polat, 2000). The practical significance of the work is empirical studies, which based on statistical analysis and indicating training strategies for the self-educational and cognitive activity of students (Lapteva\&Projoga, 2017).

For the first time, a list of training strategies was compiled in '70 in the Canadian Institute of OISE (Ontario Institute for Studies in Education), where learning activities of students, who successfully learned the spoken foreign language, were studied. The aim of the research was to find ways to achieve the desired results in training (Stern, 1979; Canale\& Swain, 1980).In this paper, strategy refers to the method to perceive foreign speech and to get information from a 
professionally-oriented communication, which is implemented on the basis of personal intentions and professional experience to be explicated in tactics.

\section{MAIN FINDINGS}

In order to all functions of the strategies were maximum involved in extracurricular educational activities, this study was conducted in two stages:

- The first or preparatory stage: questioning of students and processing of survey results.

- The second stage is based on the results of the first one and includes systematization of students' knowledge about independent learning and cognitive activity for professional goals, tools, and strategies for autonomous training.

Consider these stages in more details:

The first stage of research work

Teachers of Foreign Languages Department of Mordovia State University (Educational programs, 2018) have developed a questionnaire "The reasons for continuous foreign language training for bachelor/master students at nonlinguistic departments" for statistical analysis among students on nonlinguistic faculties.

Table1: Sample of a completed questionnaire for students in the survey conducted "Reasons for continuous foreign language training for students at nonlinguistic departments"

\begin{tabular}{|l|l|c|c|c|}
\hline No & $\begin{array}{l}\text { Reasons for continuous foreign language training for } \\
\text { students at nonlinguistic departments }\end{array}$ & Yes & No & $\begin{array}{c}\text { Hard } \\
\text { to say }\end{array}$ \\
\hline 1 & $\begin{array}{l}\text { The prerequisite for successful training in a magistracy/ } \\
\text { postgraduate study not only in Russia but also abroad }\end{array}$ & + & & \\
\hline 2 & $\begin{array}{l}\text { The opportunity to participate in scientific scholarship } \\
\text { programs }\end{array}$ & + & + \\
\hline 3 & $\begin{array}{l}\text { Taking part in students/ young professionals' exchange } \\
\text { between Russian and international peer universities }\end{array}$ & & & + \\
\hline 4 & $\begin{array}{l}\text { Participation in international educational projects and } \\
\text { competitions }\end{array}$ & & & + \\
\hline 5 & $\begin{array}{l}\text { Multicultural interaction with native speakers of a foreign } \\
\text { language and foreign culture both in person and on social } \\
\text { networks }\end{array}$ & & + \\
\hline 6 & $\begin{array}{l}\text { Professional development of future specialists in their } \\
\text { fields through business internships }\end{array}$ & & + & + \\
\hline 7 & Knowledge of two or more foreign languages & & + & + \\
\hline
\end{tabular}

The survey involved full-time bachelor students of the $3 \mathrm{~d}$ and 4 th year of study and full-time master students (100 people) of different specialties: Veterinary Medicine, Jurisprudence, Economics, Agriculture, and Light Engineering.

The participants of the survey expressed anonymously their position for reasons for continuous foreign language training which in Figure. 1 are marked:

1. the prerequisite for successful training in a magistracy/ postgraduate study not only in Russia but also abroad;

2. the opportunity to participate in scientific scholarship programs;

3. taking part in students/ young professionals' exchange between Russian and international peer Universities;

4. participation in international educational projects and competitions to get foreign language experience (linguistic competence);

5. multicultural interaction with native speakers of a foreign language and foreign culture both in person and in social networks (socio-cultural competence);

6. professional development of future specialists in their fields through business internships (socio-professional competence);

7. the formation of a multicultural personality, a command of the native (Russian), national (Mordovian) and min. two foreign languages.

The results of the questionnaire showed that the students' main reasons for continuous foreign language learning during senior courses are: internships (100\%), intercultural interaction (80\%), the ability of scientific (50\%) and training (46\%) 
experience exchange, a magistracy/postgraduate study $(65 \%)$, and participation in international grant programs and projects $(41 \%)$.

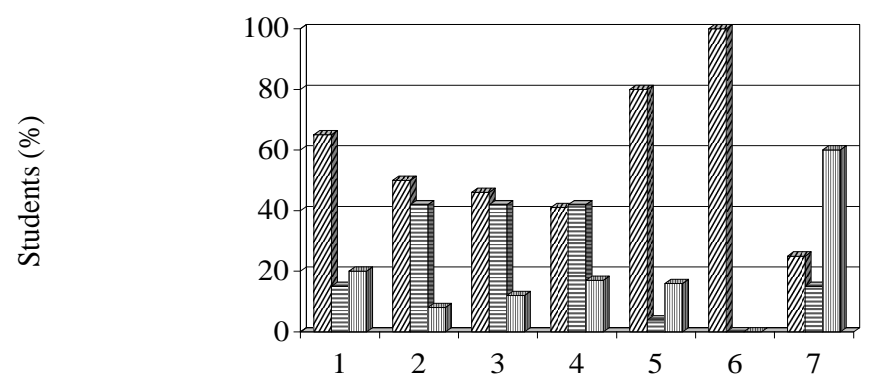

Reasons for language training

物Yes 自No Hard to say

Figure 1: The results of the survey "The reasons for non-interruption foreign language training of non-linguistic departments".

Despite the fact that many students speak one of the national languages of the Russian Federation and thus are bilingual, it is a regrettable fact that a small proportion of respondents $(25 \%)$ wish to learn more than one foreign language. However, students willingly participate in international projects.

Thus, the results of the survey revealed an urgent need to establish a differentiated system of independent educationalcognitive activity and plan the strategies, which are suitable for target groups from different professional fields. Therefore, a temporary gap in language education should be completed with some additional language training (Bocharova, 2008; Lapteva\&Projoga, 2017 and others). To do this, a temporary gap in language education has to be filled (5-8 terms of undergraduate) by autonomous extracurricular education.

Such autonomous training contributes to maintaining the proper level of foreign language skills and the ability to use it in professional communication. Thereby this activity meets Russian and foreign companies' needs in employees, who have, in addition to their professional skills, such competence as linguistic, communicative, and sociocultural, etc. (Common European framework, 2005).

\section{The second stage of research work:}

Therefore, the main task of a teacher is to maximize the mental activity of a student in the process of autonomous training. This can be achieved through various "tools", which means alternative possibilities of independent study of a foreign language in extracurricular time. These include:

- Electronic resources specifically developed by teachers of the University. It can be general public information sites or sites devoted to a particular academic discipline or activities of a teacher. For example, for autonomous extracurricular learning, the educational website "English for Agronomy students" on the basis of the educational and methodical complex was specially designed and tested in the process of independent educational-cognitive activity http://agronomy1.wixsite.com/english

The structure of the site comprises 7 modules, each of them has its own lexical and grammatical content, interactional and creative tasks. The first four can be used by students of every specialty and the other three (5-7) contain professional lexical units for agronomy only. Such for structure can help every student to start his/ her self-education from any stage of foreign language knowledge.

The process of using electronic resources expands students' knowledge and horizons, develops their cognitive functions and logic of thinking, updates professional knowledge based on progressive technologies.

- Translation of special literature also can be used as a tool for autonomous training and cognitive training. For example, as additional learning for the special training course "Foreign language for a special purpose", or as preparation for Master course study.

Within this self-educational-cognitive activity, along with metacognitive strategies (described in Literature Survey) cognitive (direct) strategies are involved. Among them, according to Bimmel\&Rammpillon (2000), can be stood out text and linguistic strategies (structuring of the text, finding and highlighting important information by its marking; the use of drawings, photos, and diagrams accompanying text (for a preliminary text understanding); the semantic division of the text, restore the deformed text; analysis to identify patterns; use dictionary, grammar books). 
These strategies are used in the following tactics: translation of technical documents for machinery and equipment (user manual, repair and maintenance, etc.); translation of relevant scientific and technical information and innovative technologies as a permanent development of technology demands the latest information from specialized magazines; translation of messages from industrial fair, the largest centers and enterprises, promoting international cooperation.

- Along with translation practices and educational web sites, there are many additional possibilities that can be considered as tools of autonomous foreign language learning in the modern society: many educational groups on the Internet, where administrators post and share scientific and cultural information, interesting facts, information from the professional sphere of activity, etc. and train lexical, grammatical, and communicative skills.

- Learning international and national competitions/projects require knowledge of foreign languages and knowledge of the profession and motivate continuous language training via multimedia presentations (Raptanova, 2009).

- The students are candidates of the refreshment programs, scholarships for training or research projects, etc. For example, Agrarianstudentsareactivelyengaged in the program "Landwirtschaftliches ökologisches Gleichgewicht mit Osteuropa“ http://logoev.de.

- Contacts with foreign students of Mordovia State University, as well as contacts with the Purpose of "friends" in social networks (e.g. Facebook, Skype, etc.) is quite important for intercultural communication.

- Independent educational and cognitive activity of the students is also supported in additional foreign language courses (training in language centers, schools of foreign languages, distantly on the platform of e-Learning, tutoring, etc.).

Such tools facilitate the use of metacognitive and cognitive strategies for supporting autonomous foreign language training for intercultural professional communication.

\section{DISCUSSION}

Complementing the classification of P. Bimmel\& W. Rammpillon (2000), we believe that for intercultural communication are also important Communication strategy involving such aspect as: justification of one's own opinion; the explanation of one's own algorithm of actions; a critical evaluation of different points of view; self-reflection of the learning activity ways for foreign language text. In our opinion, these strategies should be added to the strategy of social interaction.

The typology of communication strategies contains such strategies as:

- avoidance strategies (to avoid certain topics, as the student is afraid of his insufficient language skills to communicate);

- rephrasing strategies (replacing missing lexemes with an approximation, word formation process, paraphrasing);

- transfer strategies (literal translation from the native language, borrowing words from the native or another language), requests for help, facial expressions, gestures.

Based on D. Wolf's classification, we add to the communication strategies the next ones:

- language units' operation strategies (Wolff, 1992). Operational instructions for action, training and work activities (actions for learning vocabulary, actions for organizing learned vocabulary: such as fields of words, word families, word scale; texts reconstruction, etc.);

- skill strategies (Rampillion, 1989). Instrumental process of work during texts reception and reproduction, for example, "note-taking"; division, preparation of instrumental planning actions by writing (Matrixtechnik, Pyramidentechnik); the process of self-management and -control of mental processes; methods of active reading and structuring texts through mark-making; keyword orientation; disclosure of unfamiliar word meaning, etc.

- language reflection strategies (Bialystok, 1987). Strategies of segmentation, classification, and generalization ("control of processes" - the emphasis on language form and language expression content, comparing speech structures with each other, "data-driven learning", collecting language data, its systematic compilation using new technologies, data classification, etc.)

It has to be explained why communication strategies are so important and are given so much attention. As the higher education is entirely based on competence mastering approaches, future specialists are to take into account not only professional competences but communicative and sociocultural ones to become a part of multicultural and global economy. Communication strategies are a part of foreign language communicative competence.Only if they are completely mastered, intercultural communication will be successful.Thus, competence reflects a person's readiness to perform certain activities and includes not only cognitive (skills, knowledge), but also non-cognitive (motivation, characters of values, ethical attitudes, etc.) components. And only if a student realizes the usefulness of learning communication strategies, he will be able to use them in speech practice. After all, a student who does not know the strategies of verbal behavior will face many obstacles in the process of communication and interpersonal relations, which are the "base" and the "foundation" for further contact of interlocutors. According to Canale\& Swain (1980), the four main sub-competencies are necessary: 
- grammatical (the skill to generate grammatically structures),

- discourse (the skill to produce logical and intelligible statements),

- sociolinguistic (the skill to make sociolinguistically correct statements), and

- strategic (the skill to solve problems during communication).

In our opinion, the last one takes the maimed part in autonomous foreign language training.

In this study, we highlight the following functions of strategies of a foreign language learning, based on the classification by P.Bimmel\& U. Rammpillon (2000): 1) increasing the effectiveness of learning; 2) motivation and belief in one's own strength; 3) independence; 4) self-education; 5) the transfer of obtained experience in other learning and life contexts.

In our opinion, the following are also crucial in developing training strategies:

- development of self-reflective competence (discursiveness, self-observation) in group work: the ability to think through own language processing and self-learning, for example, What am I doing, if I say or read something? etc., What do I do when I learn a foreign language? The development of skills that will help to critically consider one's own self-reflection;

- the choice of training and work activities that can be independently tested by students and checked for their suitability, therefore the link between educational autonomy and educational and work activities becomes apparent;

- selection of tools - "cognitive tools" (D. Wolf), which allow the student to construct his own hypothesis. There suggests computer use: "semantic networking", "expert-system", "hypertext systems", "micro-words" (simulations), "templates", "navigation aids";

- choice of learning environment where students can test their hypotheses. Many opportunities are provided with new information technologies.

The content of the autonomous training of undergraduate and master students can be realized with the help of the mentioned cognitive tools.

\section{CONCLUSION}

The main objective of independent educational and cognitive activity of students is to acquire relevant scientific knowledge through personal searches, active interest and creative approach to intercultural, scientific and professional communication.

Independent educational and cognitive activity of students must meet such didactic requirements as (Ivlevaet al., 2018): a) form skills and abilities for the growth of student's autonomy, the development of individual's subjective thinking and educational reflection; b) be relevant in the chosen occupation, stimulating cognitive activity; c) assist in providing new professional information from special literature and other sources of information in a foreign language; d) develop intercultural communication in a foreign language, which is initiated for the reasons noted above in Table 1 and Figure 1.

Summarizing the above, it should be noted that because of the absence of academic hours for Foreign language discipline in Federal State Educational Standards for bachelor and master students, autonomous learning through training strategies should become an alternative component of contemporary professional education.

The opportunity of students of nonlinguistic departments to choose and coordinate a training strategy, to plan their own actions and operations will help them to optimize professionally-oriented language training. The use of such strategies has a positive effect on the formation of a student's personality, on making decisions independently in the process of foreign language learning, and on the formation of personal qualities contributing to successful educational and professional achievements.

\section{LIMITATION AND STUDY FORWARD}

The strengthening of European integration allows Russian students of nonlinguistic faculties to study abroad and to improve the skills that require language knowledge, communicative skills, and abilities, specific professional experience, basic principles of intercultural cooperation and motivation for self-improvement. The pedagogical experiment of this study showed they can be reached through independent educational-cognitive activity, which can be studied in the next papers.

\section{ACKNOWLEDGMENTS}

This paper is based on a research project of Mordovia State University, Strategies of Continuous Foreign Language Training". The authors would like to thank then on linguistic students and colleagues from Foreign Language Department the opportunity to approve the main conclusions of this scientific works and colleagues from for helping to conduct the research and their active discussion about the high school educational problems regarding this research. 


\section{REFERENCES}

1. Bermus, A.G. (2003). Upravleniekachestvomprofessional'no-pedagogicheskogoobrazovaniya - in Russian[Quality management of professional-pedagogical education]: (Doctoral dissertation). Rostov-on-Don State Pedagogical University, Rostov-on-Don. Retrieved from http://nauka-pedagogika.com/pedagogika-13-0008/dissertaciya-upravlenie-kachestvom-professionalno-pedagogicheskogo-obrazovaniya /

2. Bialystok, E. (1987). Influences of Bilingualism on Metalinguistic. Second Language Research, vol. 3, $154-166$. https://doi.org/10.1177/026765838700300205

3. Bimmel, P., \&Rammpillon, U. (2000). Lernautonomie und Lernstrategien (Ed.) München, GIN.

4. Bocharova, E.P. (2008). Akmeologicheskijpodhod k obrazovaniyu[Acmeological approach to education]. Humanities research in Eastern Siberia and the Far East[Gumanitarnyeissledovaniya v VostochnojSibiriinaDal'nemVostoke - in Russian]: Scientific journal, 4, 5-10. Retrieved from https://elibrary.ru/download/elibrary_14435485_68606240.pdf

5. Canale, M., \& Swain M. (1980). Theoretical Bases of Communicative Approaches to Second Language Teaching and Testing, Applied Linguistics, 11-47. Retrieved from https://doi.org/10.1093/applin/I.1.1

6. Cofer, D. (2000). Informal Workplace Learning. U.S. Department of Education: Clearinghouse on Adult, Career, and Vocational Education: Practice Application Brief, $10 . \quad$ Retrieved fromhttp://files.eric.ed.gov/fulltext/ED442993.pdf

7. Obshcheevropejskiekompetenciivladeniyainostrannymyazykom: Izuchenie, obuchenie, ocenka - in Russian(2005). [Common European framework of reference for languages: Learning, teaching, assessment] (Ed.) Transl. by Prof. K. Iriskhanova. Moscow, Strasbourg, The Department for language politic. Retrieved from http://ebcl.eu.com/wp-content/uploads/2011/11/CEFR-all-scales-and-all-skills.pdf

8. Educational programs of higher education - undergraduate, graduate, specialty (2018). Ogarev Mordovia State University (Saransk): Public homepage. Retrieved from https://www.mrsu.ru/en/edu/spec edu3/

9. Ellis, R. (1994). The Study of Second Language Acquisition. Oxford, Oxford University Press.

10. Federal state educational standards of higher professional education (2018). Portal of Federal state educational standards of higher professional education: Public homepage. Retrievedfromhttp://fgosvo.ru/

11. Huneke, H.W. (2000). Deutsch als Fremdsprache: Eine Einführung (Ed.), 2-d ed. Berlin.

12. Ivleva, A.Yu., Lapteva, I.V., \&Sonyem, A.B. (2018).Topical issues of bachelor-translator's basic linguistic training in higher school: the introduction of communicative-functional approach to translationteaching. Integration of Education: Vol. 22, 2(91), 324-338. DOI: 10.15507/1991-9468.091.022.201802.324-338. Retrieved fromhttps://elibrary.ru/download/elibrary 35161770_88056161.pdf.https://doi.org/10.15507/19919468.091.022.201802.324-338

13. Katchalov, N.A. (2004). Nepreryvnoeobrazovanie: izuchenieinostrannogoyazyka- in Russian [Continuing education: learning a foreign language]. VestnikTomskogogosudarstvennogouniverstiteta- in Russian[News of Tomsk State University]: Scientific journal, 282, 250-256. Retrieved from http://journals.tsu.ru/vestnik/\&journal_page=archive\&id=792\&article_id=6190

14. Lapteva, I.V., \&Pahmutova, E.D. (2010). Prepodavatel' inostrannogoyazykakakt'yutorpriformirovaniilingvoisociokul'turnyhznanij- in Russian [The foreign language teacher as a tutor during the formation of the linguistic and sociocultural knowledge]. Gumanitarij: aktual'nyeproblemynaukiiobrazovaniya- in Russian[The humanitarian: the actual problems of science and education]: Scientific journal, 1 (9), 59-65. Retrieved from https://elibrary.ru/download/elibrary_15115938_32786691.pdf

15. Lapteva, I.V., \&Projoga, A.V. (2017). Predposylkiavtonomnogoobucheniyainostrannomuyazykustudentovagrariev - in Russian [Prerequisites for foreign language autonomous training of agrarian students]. 13-th Intrn. conf. (pp 587-590), Saransk. Retrieved fromhttps://mrsu.ru/ru/i_faculty/acts.php?ELEMENT_ID=65462

16. Mitusova, O.A. (2008). Kompetentnostnyjpodhod k obucheniyuiyazykovayalichnost' - in Russian [Competencebased approach to learning and language identity]. Vyssheeobrazovaniesegodnya- in Russian[Higher education today]: Scientific journal, 6, 26-28.

17. Polat, E.S. (2000). Metodproektovnaurokahinostrannogoyazyka- in Russian [Method of projects at foreign language lessons]. Inostrannyeyazyki v shkole- in Russian[Foreign languages at school]: Scientific journal, 3, 37-45. Retrieved from http://schools.keldysh.ru/labmro/lib/polat3.htm

18. Rampillon, U. (1989). Lerntechniken / Bausch, K.-R., Christ, H., Huellen, W. et al. HandbuchFremdsprachenunterricht (Ed., pp 215-218). Tübungen, Francke.

19. Raptanova, I.N. (2009). Prezentaciyakakodinizvidovsamostoyatel'nojrabotystudentov- in Russian [Presentation as one of the types of independent work of students]. Regional'nyj portal obrazovatel'nogosoobshchestvaOrenburzh'ya- in Russian[Regional portal of the educational community of $\begin{array}{lllll}\text { Orenburg } & \text { region]. } & \text { Orenburg, } & \text { OSU. } & \text { Retrieved }\end{array}$ http://www.orenport.ru/docs/281/work_stud/Members/Raptonova.htm

20. Sazonov, B.A. (2006). Bolonskij process: aktual'nyevoprosymodernizaciirossijskogovysshegoobrazovanii - in Russian[The Bologna process: actual problems of modernization of Russian higher education] (Ed.) Moscow.

21. Slastenina, V.A., et al. (2006). Pedagogikaprofessional'nogoobrazovaniya - in Russian[Pedagogy of professional education] (Ed.). Moscow, Academia. 
22. Stern, H. H. (1979). Language learning on the spot: some thoughts on linguistic preparation for bilingual student exchanges. Toronto: The Ontario Institute for Studies in Education. Mimeo.

23. Stork, A. (2011). Was? Wie? Warum? Reflexion anleiten (Goethe-InstitutHeft): Zeitschrift für die Praxis des Deutschunterrichts, 45, 27-30. Donauwörth, Hueber Verlag GmbH \& Co KG.

24. Wolff, D. Lern- und Arbeitstechniken für den Fremdsprachenunterricht: Versuch einer theoretischen Fundierung (1992). Multhaup, U., \& Wolff, D. Prozessorientierung in der Fremdsprachendidaktik (Ed.) (pp 101-120). Frankfurt, Diesterweg.

25. Yakimanskaya, J.S. (1995). Razrabotkatekhnologijlichnostno-orientirovannogoobucheniya - in Russian [The development of technologies for student-centered learning]. Voprosypsihologii - in Russian[The Issues of Psychology]: 2, 28-37. Retrieved from http://koi.tspu.ru/koi books/nikolskaya2/rtloo.htm

26. Zimnyaya, I.A. (2013). Pedagogicheskayapsihologiya - in Russian[Pedagogical psychology] (Ed.) Moscow, MPSU.Retrieved from http://sdo.mgaps.ru/books/KP1/M4/file/2.pdf 